\title{
How Twitter affects academic library users
}

\author{
Dessy Harisanty
}

\section{Introduction}

Twitter as a social media platform plays a significant role in disseminating information compared with other social networks such as Facebook, Instagram and Line. Given the benefits of Twitter, it can be used as a medium of information for college libraries, and one such example is Airlangga University's library. The Airlangga University's library has also utilized Twitter for the dissemination and promotion of information activities. The library has been registered on Twitter as @unairlibrary since December 2011 (https://twitter.com/unairlibrary?lang= en). As of this writing, at least 12,700 tweets have been published by the library, and its account has 6,174 followers. We were interested to determine the influence Twitter has as a medium for information from the library and its effect on library use. We have also included a general discussion on Twitter and libraries.

The study looked at the satisfaction levels proposed by Blumer and Katz (Griffin, 2003) showing how individuals are active in selecting media to meet their needs. In our sample, we considered the students who visited the library's Twitter account for at least three times in a month. The study includes results from 220 respondents. We made use of a multiple linear regression test analysis using the following variables: monitoring $\left(X_{1}\right)$, diversion/entertainment $\left(X_{2}\right)$, personal identity $\left(X_{3}\right)$ and social relationships $\left(X_{4}\right)$ with library use $(Y)$. The null hypothesis in this study is that there is no influence of the existence of a library's Twitter account on actual library use.

\section{Study results}

Arisandy (2009) affirms that students want to stay connected to the internet. Twitter has its own character when compared with other social media; there is a limit for "tweets" of 140 characters, and because of this fact, the information submitted is more concise and can be read quickly (Johnson, 2014). The behavior of respondents was more difficult in locating information by asking a friend is 58.2 per cent. McCaskill (2015) notes that information needs are met with recommendations and opinions from friends, because there is a high level of trust as compared with the trust in search engine results.

Table I demonstrates the results of a t-test of monitoring library use. Judging from the value of $t$ in Table I, a 3.30 multiple linear regression model, the first variable $\left(X_{1}\right)$ has a $t$ count of -1.193 smaller than the $\mathrm{t}$ table of $-1.97(d f=217$ and $\alpha=5$ per cent). From the results of the t-test, we can reject the null hypothesis that supervision $\left(X_{1}\right)$ has a significant role on library utilization. The overall level of user satisfaction on monitoring variables is 3.80 , demonstrating a positive impact for the Airlangga's University library. From the use of the library's Twitter feed, the library seems to have a special place in sharing latest information to not just the library users but also the general public who are interested in the new information being shared (Milstein, 2009; Le Gac, 2010; Ho and Hsiang, 2010; Bachrach, 2010; Dickson and Holley, 2010). The results of a study by Stuart (2010) show that an average of 30 per cent of the libraries of the 433 Twitter accounts studied make at least one post per day and that 59 per cent of the libraries have followers of less than 100.

When we analyzed the $X_{2}$ variable related to diversion and entertainment and compared it with library use and a t-table of 3.30, we found that the diversion/ entertainment variable $\left(X_{2}\right)$ has a $t$ count (3.329) larger than the t-table of $1.97(d f=$ 217 and $\alpha=5$ per cent). From the results of t-test, we can reject the null hypothesis and conclude that diversion/entertainment has a significant influence on library utilization. Factors of diversion/ entertainment in this study had an average score of 3.42, equating with a high satisfaction level. The librarys' Twitter feeds can enhance creativity with a good satisfaction level of 3.50. The use of Twitter to relieve stress also had a high satisfaction score of 3.24. Based on these results, library Twitter feeds should maximize their entertainment value considering that this variable has a significant influence on the level of library use.

When we looked at the $X_{3}$ personal identity variable with library use and a ttable value of 3.30 using a multiple linear regression model, we found a $t$ count of 2.661, which is larger than the ttable of 1.97 ( $d f=217$ and $\alpha=5$ per cent). From this result, we can reject the null hypothesis and interpret that personal identity has a significant influence on library use. This compares with the level of user satisfaction of Facebook having an average satisfaction score of 3.56. Twitter had a higher satisfaction score of 3.83, which is in line with the research carried out by Del Bosque et al. (2012) who found that the use of a Twitter by a library is to convey information about the library. Cuddy et al. (2010) found that Twitter may be the best way to collect feedback from library users about library services, hours, classes and so on. By monitoring and listening to library Twitter followers, libraries have the opportunity to fix problems quickly, gain user opinion and basically listen to criticism and suggestions from users without the use of a survey instrument. Research conducted by Mathews (2008) on the use of Twitter by college libraries found that they can provide information about workshops and other events held in the library and also provide the information related to library policies. 
Table I.

Results of multiple linear regression analysis

\begin{tabular}{lcrr}
\hline Variable & Coefficient & $t$ & Significance \\
\hline Constant & 8.944 & 6.198 & 0.000 \\
Surveillance $\left(X_{I}\right)$ & -0.119 & -1.193 & 0.234 \\
Diversion/entertainment $\left(X_{2}\right)$ & 0.459 & 3.329 & 0.001 \\
Personal identity $\left(X_{3}\right)$ & 0.327 & 2.661 & 0.008 \\
Social relationship & 0.441 & 3.736 & 0.000 \\
$R$ & $=0.658$ & $\mathrm{~F}$ & $=41.117$ \\
$R^{2}$ & $=0.433$ & $\mathrm{~F}_{\text {table }}$ & $=3.06$ \\
& & Sig F & $=0.000$ \\
Source: Primary data are processed & & $\mathrm{t}_{\text {table }}$ & $=1.97$
\end{tabular}

The $X_{4}$ variable of social relations related to library use demonstrated a significant influence on library utilization. The t-test had an average score of 3.67. We found that Twitter can be an effective way for students to communicate with the library. Instead of physically coming to the library, the library can provide services remotely to users via Twitter (Casey and Savastinuk, 2006). Twitter can be used to learn what users think about the library and what users do with their time spent in the library (DeVoe, 2009). The same is also expressed by Huang et al. (2017) that a library can use Twitter to better understand user needs. According to Bell (2009), library tweets can be equated with academic success. Fields (2010) indicated that Twitter can be used as a virtual reference service. Another study found that using Twitter for reference had a positive effect on academic performance, student involvement and motivation (Junco et al., 2011). Twitter can also be used to promote the development of interest in reading and to promote library resources and services. Huang et al. (2015) found that Twitter can promote online access.

Merging all variables together (Ftest) proved that there is a significant influence of satisfaction levels on library use. According Tciptopranoto and Silitonga (2008), the use of the library includes the use of collections and various services available in the library. The utilization of the library includes the frequency of visits to the library, the introduction of services and the use of collections available. Taken as a whole, users are satisfied in using the library.

\section{Conclusion}

University libraries are required to always be able to meet the information needs of its users. In the era of civitas academica familiar with the existence of social networking medium Twitter, Airlangga University's library also welcomed a Twitter account that provides information related to the activities and other relevant information. Based on the results of research, it can be concluded that the user satisfaction of social networking medium such as Twitter, which includes variable monitoring, diversion/ entertainment, personal identity and social relationship, either partially or simultaneously, influences the use of the library and user satisfaction.

\section{REFERENCES}

Bachrach, H.C. (2010), "Being there is only the beginning: towards more effective web 2.0 use in academic libraries", Information Science and Technology Directorate Research Report (DTIC-E-TR-2010/06).

Bell, S. (2009), "Is Twitter a must for academic libraries?", Library Journal, available at: www.libraryjournal.com/ article/CA6659755.html

Casey, M.E. and Savastinuk, L.C. (2006), "Library 2.0: service for the next-generation library", Library Journal, Vol. 131 No. 14, pp. 3-15.

Cuddy, C., Graham, J. and Morton-Owens, E.G. (2010), "Implementing Twitter in a health sciences library", Medical Reference Services Quarterly, Vol. 29 No. 4, pp. 320-330.
Del Bosque, D., Leif, S.A. and Skarl, S. (2012), "Libraries atwitter: trends in academic library tweeting", Reference Services Review, Vol. 40 No. 2, pp. 199-213, available at: https://doi.org/10.1108/00907321211228246

DeVoe, K.M. (2009), "Bursts of information: microblogging", The Reference Librarian, Vol. 50 No. 2, pp. 212-214.

Dickson, A. and Holley, R.P. (2010), "Social networking in academic libraries: the possibilities and the concerns", working paper No. 33, available at: http://digitalcommons. wayne.edu/slisfrp/33

Fields, E. (2010), “A unique Twitter use for reference services", Library Hi Tech News, Vol. 27 Nos 6/7, pp. 14-15.

Griffin, E.M. (2003), A First Look At Communication Theory, Mcgraw-Hill, London.

Ho, H.I. and Hsiang, J. (2010), "Effectiveness of social networking in a university environment", available at: http://gra103.aca. ntu.edu.tw/gdoc/99/D93922021a.pdfhttps:// twitter.com/unairlibrary?lang=en

Huang, H., Chu, S.K.W. and Chen, D.Y.T. (2015), "Interactions between Englishspeaking and Chinese-speaking users and librarians on social networking sites", Journal of the Association for Information Science and Technology, Vol. 66 No. 6, pp. 1150-1166.

Huang, H., Kai Wah Chu, S., Yuyang Liu, L. and Yi Zheng, P. (2017), "Understanding user-librarian interaction types in academic library microblogging: a comparison study in Twitter and Weibo", Journal of Academic Librarianship, p. 1, available at: https://doi. org/10.1016/j.acalib.2017.06.002

Johnson, P.R. (2014), "Toward a uses and gratification's model of Twitter", Theses, pp. 1-92.

Junco, R., Heiberger, G. and Loken, E. (2011), "The effect of twitter on college student engagement and grades", Journal of Computer Assisted Learning, Vol. 27 No. 2, pp. 119-132.

Le Gac, M.A.O. (2010), “Twittering libraries: how and why New Zealand public libraries use microblogging", available at: http:// researcharchive.vuw.ac.nz/bitstream/handle/ 10063/1402/thesis.pdf.txt?sequence $1 / 44$

McCaskill, A. (2015), "Recommendations from friends remain most credible form of advertising among consumers; branded websites are the second-highest-rated", available at: www.nielsen.com/ug/en/pressroom/2015/recommendations-from-friendsremain-most-credible-form-of-advertising. html 
Mathews, B. (2008), "Twitter and the library: thoughts on the syndicated lifestyle", Journal of Web Librarianship, Vol. 2 No. 4, pp. 589-593.

Milstein, S. (2009), "Twitter for libraries (and librarians)", Computers in Libraries, Vol. 29 No. 5, p. 2.

Stuart, D. (2010), "What are libraries doing on Twitter?", Online, Vol. 34 No. 1, pp. 45-47.

\section{FURTHER READING}

Assegaf, J.S. (2014), "Media sosial terlaris: ini keunggulan twitter dibanding Facebook dan Instagram", Solopos, available at: www. solopos.com/2014/12/30/media-sosial-terlarisini-keunggulan-twitter-dibanding-facebookdan-instagram-563081

Zuraida, S. (2011), Persepsi Mahasiswa terhadap Fungsi Perpustakaan sebagai Sumber Informasi. (Skripsi), Universitas Airlangga, Surabaya.
Dessy Harisanty (dessy.harisanty@ vokasi.unair.ac.id) is based at the Department of Library Studies, Universitas Airlangga, Surabaya, Indonesia. 